\title{
Changes in epigeic spider community in primary succession on a brown-coal dump
}

\section{Stanislav PEKÁR}

\begin{abstract}
Changes in epigeic spider community in primary succession on a browncoal dump. A descriptive model of primary succession of spiders on a brown-coal dump is presented. Multivariate methods (cluster analysis and detrended correspondence analysis), and community indexes were applied to evaluate changes in community composition of epigeic spiders. Two different rehabilitation age stages were investigated. The cluster analysis helped to determine a case of horizontal asynchronous succession. The DCA was able to distinguish divergent trends of succession from the initial stage. Successional trends in species replacements were observed. In all aspects of succession there was found to be directional towards a „ruderal steppe" subclimax.
\end{abstract}

Key words: Primary succession, spiders, mine dump, diversity, ordination, cluster analysis, Slovakia

\section{INTRODUCTION}

Consideration of ecological succession has attracted ecologists for almost a hundred years. In recent decades, more and more attention has been paid to newly formed or disturbed sites resulting from human activity (e.g. MAJER 1990). Mining, particularly for coal, is one of the most disturbing human activities in central Europe. The side product of mining activity is dumped on huge dumps which can dominate the landscape. In Bohemia, for instance, there are about $200 \mathrm{~km}^{2}$ of such sites (PRACH 1987). These areas have to be restored, therefore monitoring of community development is necessary.

The succession of many taxa has been studied on mine dumps in Europe. Most frequently studied groups were the plants (e.g. PRACH 1987), followed by beetles (e.g. VOGEL \& DUNGER 1991), soil invertebrates (e.g. DUNGER 1991), vertebrates (e.g. BEJČEK 1983) and also spiders (e.g. BROEN \& MORITZ 1965). Consequently, a number of models 
describing succession have been proposed (LEPŠ 1988). Descriptive models have been most frequently used for a description of succession of terrestrial invertebrates (e.g. HEJKAL 1985, DUNGER 1991).

The aim of this paper is to present the results of succession of spiders on a mine dump in Slovakia.

\section{MATERIAL AND METHODS}

The brown-coal (lignite) dump, operated by the deep mining company Baňa Nováky, is situated in the district of town Nováky (middle Slovakian region). The local altitude is $272 \mathrm{~m}$ a.s.l. The average annual temperature was $9.4^{\circ} \mathrm{C}$ in 1990 , and $9.9^{\circ} \mathrm{C}$ in 1992 , and the annual precipitation was $591 \mathrm{~mm}$ in 1990, and $629 \mathrm{~mm}$ in 1992 (Prievidza Meteorological station). The dump consists of tuff $(65 \%)$, clays ( $25 \%)$, lignite coal (5\%) and dark coal slate $(5 \%)$.

Older stage: 22- years old. The shape of the main dump is conical, with the top part cut away. The top of the dump $(0.78 \mathrm{ha})$ is $30 \mathrm{~m}$ above the ground, and was abandoned in 1968. Since then, a reclamation in late seventies was carried out, resulting in the planting of Betula pendula R. trees on S and W slopes. Except the birches, several individuals of Populus nigra L., $P$. tremula L., Pinus sylvestris L. and Salix caprea L. were naturally established. The trees attained no more than $4 \mathrm{~m}$ in height. Six types of sites $(01, \ldots .06)$ were recognized, here, according to the habitat-structure and location (the description of the vegetation-structure is not precise):

O1 - a site on W margin of the dump, trees: $P$. sylvestris, B. pendula - $5 \%$, weeds: Calamagrostis epigejos (L.)R. - 70\%, Tanacetum vulgare L., Orobanche luteaB., Epilobium collinum G., Crepis setosa H., Trifolium arvense L., Melilotus officinalis (L.)P. - altogether $5 \%$, ground: mosses and lichens (Cladonia fimbriata (L.)Fr.) - $20 \%$

$\mathrm{O} 2$ - a site on S margin, without trees, weeds: C. epigejos - $85 \%, T$. vulgare and others as in $01-10 \%$, ground: barren - $5 \%$

O3 - a site on E margin, trees: P. nigra, P. tremula and S. caprea - 30\%, weeds: Tussilago farfara L. $-5 \%, C$. epigejos $-5 \%$, ground: barren with leaf litter - $60 \%$

O4 - a site on N margin, trees: P. nigra, S. caprea - 50\%, weeds: T. farfara $-15 \%$, C. epigejos - $5 \%$, ground: barren with leaf litter $-20 \%$, mosses and lichens - $10 \%$ 
O5 - a site in N center, trees: $P$. nigra, S. caprea, $P$. tremula, $P$. sylvestris $-20 \%$, weeds: $T$. farfara $-20 \%$, C. epigejos $-10 \%$, ground: barren with leaf litter - $20 \%$, mosses and lichens - $30 \%$

O6 - a site in S center, trees: P. sylvestris - 10\%, weeds: C. epigejos - 40\%, ground: barren with leaf litter - $10 \%$, mosses and lichens - $40 \%$

Initial stage: 2- years old. Smaller conical dump arising on the side of the main dump. The top part ( 0.35 ha) was abandoned in 1990 . Without reclamation, there were no trees. Two types of sites $(11,12)$ were recognised, here (the description of the vegetation-structure is not precise):

11 - a site close to the older stage, weeds: C. epigejos - 70\%, T. vulgare - 10\%, Asperula arvensis L. - 5\%, Apera spica-venti (L.)B. - 5\%, ground: barren - $10 \%$

12 - a site on margin far from the older stage, weeds: C. epigejos - $30 \%$, T. vulgare $-10 \%, A$. arvensis - $10 \%$, ground: barren $-50 \%$

The study was performed separately in two years: the older stage in 1990 while the initial stage in 1992. As field-work had to be restricted to one fixed day a month, pitfall traps (plastic cups of 0.2 I volume, $\varnothing 7 \mathrm{~cm}$, formaldehyde fluid) were used. The traps were placed in lines (10 $\mathrm{m}$ apart) and were emptied monthly, from March to October. On each site 6 traps were set out. The data, i.e. summed annual capture taken from 6 traps on each site, were transformed into percentage values before the agglomerative hierarchical classification (cluster analysis) by the complete linkage rule. The dissimilarity between classes was measured as Euclidean distance. Detrended correspondence analysis (DCA) was used for ordination of species (HILL 1979). The Chi-square test $\left(\chi^{2}\right)$ was used to determine preference for a stage. Diversity was calculated using the Shannon-Weaver index (ODUM 1977), eveness according to PIELOU (1966).

\section{RESULTS}

Two main clusters were separated by cluster analysis (Fig. 1) revealing that sites $\mathrm{O} 1$ and $\mathrm{O} 2$ are more closely related to the initial stage sites $(11,12)$ than to the rest of $O$ sites. Further hierarchical levels show subdivision into groups: $\mathrm{O} 3+\mathrm{O} 4+\mathrm{O} 5+\mathrm{O} 6, \mathrm{O} 1+\mathrm{O} 2$ and $\mathrm{I} 1+\mathrm{I} 2$. Within $\mathrm{O} 3 . .6$ group, $\mathrm{O} 3$ is the most markedly separated, while $\mathrm{O} 4$ and $\mathrm{O} 5$ are grouped close together. According to the distance matrix $\mathrm{I} 1$ is more closely related to $\mathrm{O} 1$ and $\mathrm{O} 2$ than 


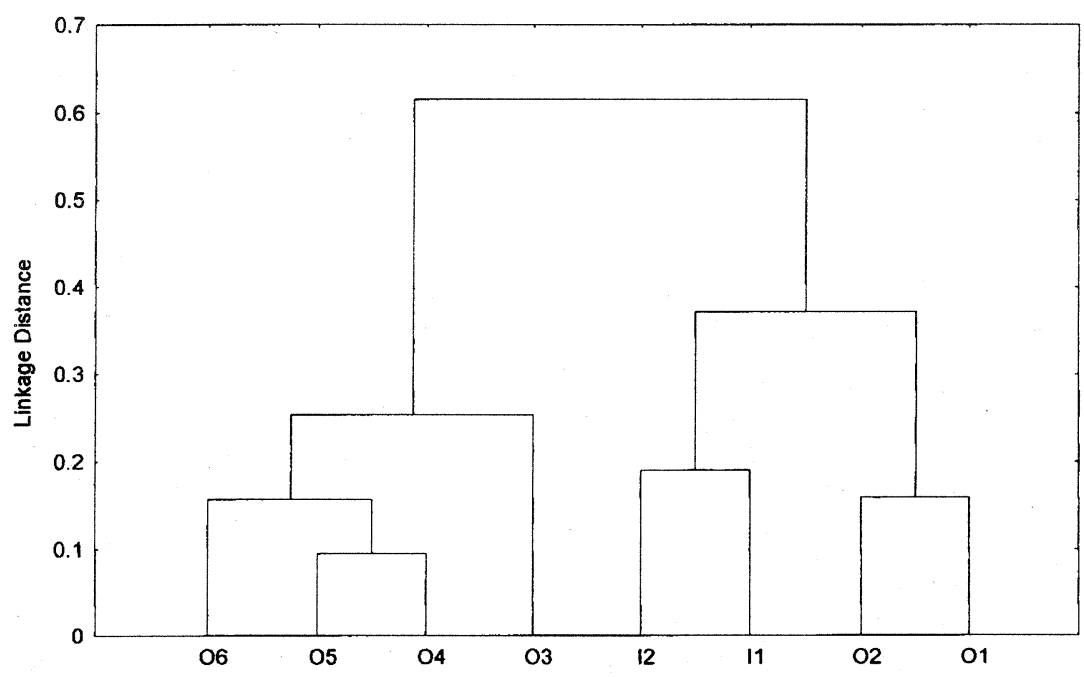

Fig. 1: Tree diagram of the sites derived from spider species composition.

12 , and $04+5$ are less distinct from 01 than from 02 . The results of the cluster analysis suggest to consider three distinct groups: $11+2,01+2$ and O3..6.

A comparison of captures (Tab. 1) show that higher annual capture per trap was recorded in initial sites of rehabilitation (34 inds. on an average) than in all $\mathrm{O}$ sites (27 inds. on an average in $01+2$ and 03..6). Similarly, a little higher number of species was obtained from sites of the initial stage than from sites of the older stage. Consequently, higher diversity and eveness indexes were obtained for the initial sites than for the older ones. Group $01+2$ was found to have a higher diversity and eveness than 03..6.

\section{Species preference}

Data on annual abundance (Tab. 1) of species were processed by DCA (Fig. 2). Obtained eigenvalues $(\lambda)$ measure the separation of species along ordination axes (HILL 1979). Axis $1 \quad\left(\lambda_{1}=0.511\right)$ distinguishes species according to the age of habitats. On the right side, at length 1.0 and more there are species that occurred exclusively in the initial stage, namely: Zodarion rubidum (5), Xysticus kochi (24), Oedothorax apicatus (6), 
Tab.1: Review of spiders collected on all sites of the mining dump (the numbers are summed annual captures), annual total of individuals per site (annual capture from 6 traps), total of species, Shannon-Weaver Index of diversity $\left(H_{s}\right)$ and evenness $(E)$.

code species and family status

\begin{tabular}{|c|c|c|c|c|c|c|c|c|c|}
\hline & Pholcidae & & & & & & & & \\
\hline 4 & $\begin{array}{l}\text { Pholcus opilionides (Schr.) } \\
\text { Dysderidae }\end{array}$ & & & 2 & & & & 1 & \\
\hline 64 & $\begin{array}{l}\text { Harpactea rubicunda (C.L.K.) } \\
\text { Zodariidae }\end{array}$ & 1 & & 10 & 3 & 3 & 1 & & 2 \\
\hline 5 & $\begin{array}{l}\text { Zodarion rubidum Simon } \\
\text { Tetragnathidae }\end{array}$ & 16 & 11 & 1 & 1 & 1 & & & \\
\hline 25 & Pachygnatha degeeri Sund. & 38 & 12 & & & & & & \\
\hline 55 & $\begin{array}{l}\text { Tetragnatha pinicola L.K. } \\
\text { Araneidae }\end{array}$ & 1 & & & 1 & & & & \\
\hline 19 & $\begin{array}{l}\text { Mangora acalypha (Walck.) } \\
\text { Linyphiidae }\end{array}$ & 1 & & & & & & & \\
\hline 16 & Centromerita bicolor (Black.) & 1 & & & & & & & \\
\hline 30 & Centromerus sylvaticus (Black.) & & & & 1 & & & & \\
\hline 13 & Dicymbium nigrum (Black.) & & 1 & & & & & & \\
\hline 38 & Diplostyla concolor (Wider) & & & 2 & & 1 & 1 & & \\
\hline 22 & Erigone atra (Black.) & 1 & & & & & & & \\
\hline 23 & Erigone dentipalpis (Wider) & 5 & 3 & & & & & & \\
\hline 28 & Microlinyphia pusilla (Sund.) & & & & & 1 & & & \\
\hline 56 & Meioneta rurestris (C.L.K.) & 6 & 1 & 3 & 2 & & & 1 & \\
\hline 57 & Mioxena blanda (Simon) & 1 & & & & & 1 & & \\
\hline 8 & Micrargus subaequalis (West.) & & & 1 & 1 & 1 & & 1 & \\
\hline 58 & Ostearius melanopygius (O.P.-C.) & & & & & & & & 1 \\
\hline 6 & Oedothorax apicatus (Black.) & 9 & 4 & & 1 & & & & \\
\hline 14 & Pocadicnemis pumila (Black.) & & 1 & & & & & & \\
\hline 26 & $\begin{array}{c}\text { Porrhomma microphthalmum } \\
\text { (O.P.-C.) }\end{array}$ & 6 & 5 & & & & & & \\
\hline 2 & $\begin{array}{l}\text { Walckenaeria capito (West.) } \\
\text { Theridiidae }\end{array}$ & & & & 1 & 2 & 2 & & 1 \\
\hline 21 & Enoplognatha thoracica (Hahn) & 3 & & & & & & & \\
\hline 17 & Robertus arundineti (O.P.-C.) & 13 & 16 & & & & & & \\
\hline 18 & $\begin{array}{l}\text { Robertus neglectus (O.P.-C.) } \\
\text { Lycosidae }\end{array}$ & 2 & & & & & & & \\
\hline 49 & Alopecosa cuneata (Clerck) & & & & & & 2 & & \\
\hline 39 & Alopecosa pulverulenta (Clerck) & & & 10 & 11 & 7 & & 6 & 2 \\
\hline 37 & Aulonia albimana (Walck.) & 1 & 2 & 11 & 1 & 1 & & & 4 \\
\hline 12 & Pardosa agrestis (West.) & 4 & 7 & & & & & & \\
\hline 54 & Pardosa hortensis (Thor.) & 1 & & & & 1 & & & \\
\hline 62 & Pardosa pullata (Clerck) & 1 & 6 & & & & & & 2 \\
\hline 15 & Pirata latitans (Black.) & & 1 & & & & & & \\
\hline 44 & Trochosa ruricola (Degeer) & 5 & 2 & 15 & 4 & 6 & 15 & 15 & 14 \\
\hline 45 & Xerolycosa miniata (C.L.K.) & 47 & 16 & 65 & 28 & 80 & 68 & 86 & 159 \\
\hline 42 & Xerolycosa nemoralis (West.) & 3 & 2 & 14 & 4 & 4 & 8 & 3 & 13 \\
\hline
\end{tabular}


code species and family status

\section{Agelenidae}

48 Cicurina cicur (Fab.)

61 Tegenaria agrestis (Walck.)

Hahniidae

32 Hahnia nava (Black.)

Dictynidae

59

Argenna subnigra (O.P.-C.)

\section{Clubionidae}

46 Cheiracanthium virescens (Sund.)

7 Clubiona compta C.L.K.

\section{Gnaphosidae}

9 Callilepis nocturna (L.)

Drassodes lapidosus (Walck.) Drassodes pubescens (Thor.) Haplodrassus signifer (C.L.K.) Micaria fulgens (Walck.) Zelotes aeneus (Simon) Zelotes pusillus (C.L.K.) Zelotes villicus (Thor.)

\section{Zoridae}

\section{Zora spinimana (Sund.)}

\section{Philodromidae}

33 Tibellus oblongus (Walck.)

\section{Thomisidae}

24 Xysticus kochi Thor.

\section{Salticidae}

10 Bianor aurocinctus (Ohlert)

11 Chalcoscirtus pseudoinfimus

$$
\text { Ovtsh. }
$$

$41 \quad$ Euophrys frontalis (Walck.)

31 Heliophanus auratus C.L.K.

27 Heliophanus cupreus (Walck.)

20 Marpissa nivoyi (Luc.)

36 Neon reticulatus (Black.)

63 Phlegra fasciata (Hahn)

29 Salticus scenicus (Cerck.)

53 Sitticus penicilatus (Simon)

1 Synageles venator (Luc.)

3 Talavera aequipes (O.P.-C.)

35 Talavera thorelli (Kulcz.)

annual total of individuals / site total of species / site

$\mathrm{H}_{\mathrm{S}}$

E

1 $\begin{array}{llllllll}11 & 12 & 01 & 02 & 03 & 04 & 05 & 06\end{array}$

$\begin{array}{llll}1 & 1 & 3 & 1\end{array}$

$\begin{array}{lllllll}6 & 5 & 2 & 1 & 1 & 1 & 3\end{array}$

$\begin{array}{lccccccc}\text { ) } & & & & 2 & 1 & & \\ & & 1 & & 1 & & 1 & \\ & & 2 & 4 & 2 & 2 & & \\ 1 & 2 & & 3 & 3 & 1 & 2 & 1 \\ 1 & & 7 & & 2 & 3 & & 4 \\ 4 & 3 & 10 & 13 & 1 & & 5 & 4 \\ & & 5 & & & & 1 & \\ 14 & 19 & 4 & 5 & 4 & 1 & 4 & \\ 4 & & 3 & 1 & 1 & & 2 & \\ 1 & 1 & & 6 & & & & 2 \\ & & & 2 & & 1 & & \end{array}$

$26 \quad 46$

1

$1 \quad 1$

$1 \quad 1$

1

$\begin{array}{llllllll}3 & 4 & 29 & 13 & 31 & 10 & 14 & 14\end{array}$

1

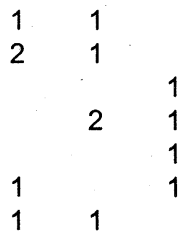

4
4
2 1

\begin{tabular}{c|c|c|c|c|c|c|c}
235 & 173 & 207 & 117 & 162 & 120 & 146 & 227 \\
37 & 26 & 29 & 29 & 29 & 17 & 16 & 18 \\
1.225 & 1.132 & 1.093 & 0.875 & 0.856 & 0.718 & 0.694 & 0.566 \\
0.781 & 0.800 & 0.747 & 0.598 & 0.585 & 0.583 & 0.576 & 0.451
\end{tabular}




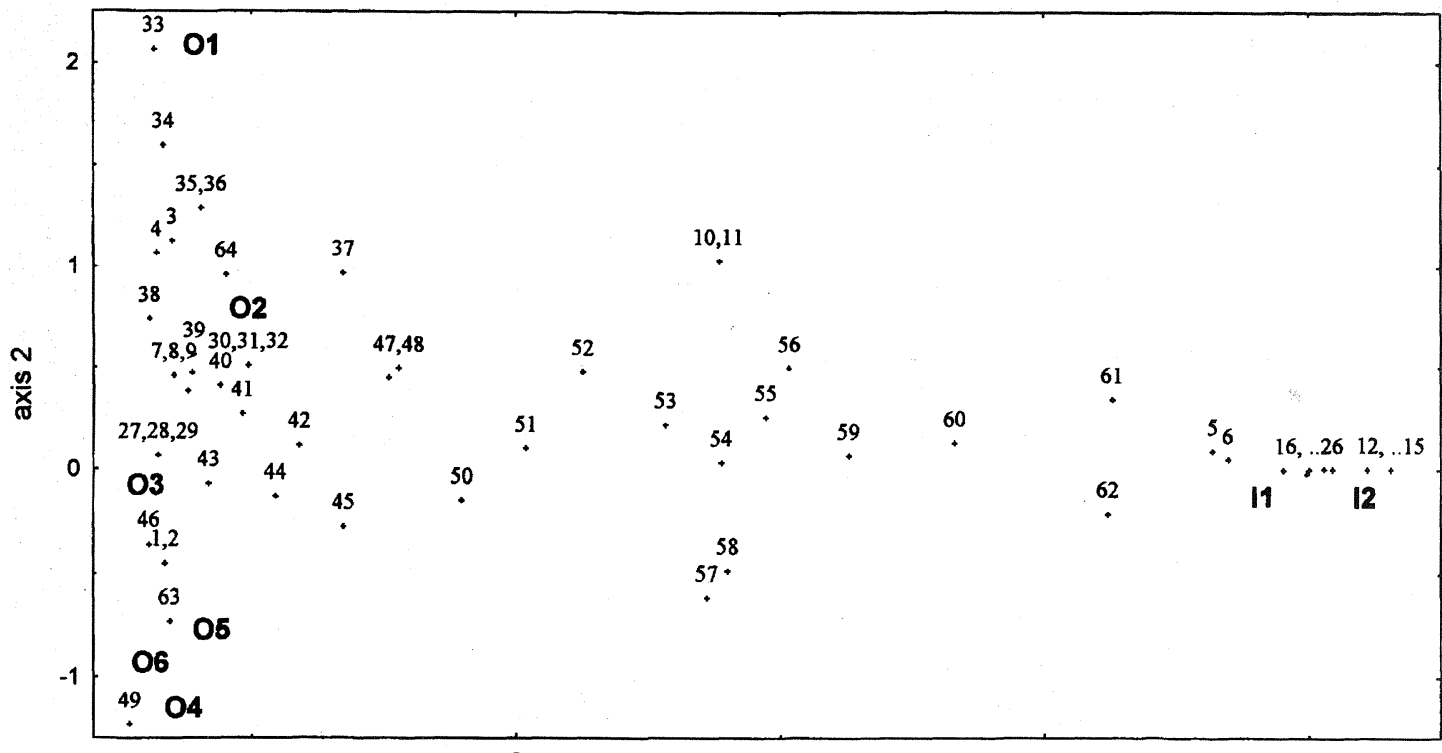

axis 1

Fig. 2: Ordination of sites and spiders.1- S. venator, 2-W. capito, 3- T. aequipes, 4- P. opilionoides, 5- Z. rubidum, 6- O. apicatus, 7- C. compta, 8- M. subaequalis, 9- C. nocturna, 10- B. aurocinctus, 11- C. pseudoinfimus, 12- $P$. agrestis, 13- D. nigrum, , 14- $P$. pumila, 15- $P$. latitans, 16- C. bicolor, 17- R. arundineti, 18- R. neglectus, 19- M. acalypha, 20-M. nivoyi, 21- E. thoracica, 22- E. atra, 23- E. dentipalpis, 24- X. kochi, 25- $P$. degeeri, 26- P. microphthalmum, 27- H. cupreus, 28- M. pusilla, 29- S. scenicus, 30- C. sylvaticus, 31- H. auratus, 32- H. nava, 33- T. oblongus, 34- M. fulgens, 35- T. thorelli, 36- N. reticulatus, 37- A. albimana, 38- D. concolor, 39- $A$. pulverulenta, 40- $D$. pubescens, 41- E. frontalis, 42- X. nemoralis, 43- Z. spinimana, 44- T. ruricola, 45- X. miniata, 46- C. virescens, 47- H. signifer, 48- C. cicur, 49- A. cuneata, 50- D. lapidosus, 51- Z. villicus, 52- Z. pusillus, 53- S. penicilatus, 54- P. hortensis, 55- T. pinicola, 56- M. rurestris, 57- M. blanda, 58- O. melanopygius, 59- A. subnigra, 60- Z. aeneus, 61- T. agrestis, 62- P. pullata, 63- P. fasciata, 64- H. rubicunda 
Pachygnatha degeeri (25), Erigone dentipalpis (23), Porrhomma microphthalmum (26) and Pardosa agrestis (12). On the left, below -0.5 length, there are species recorded only in the older stage (01..6). Axis 2 $\left(\lambda_{2}=0.126\right)$ separates species of the older stage. Habitat structure seems to be the most likely environmental aspect of this axis. Above 1.0 length there are species present only in $\mathrm{O} 1$ and $\mathrm{O} 2$, namely: Tibellus oblongus (33), Micaria fulgens (34), Talavera thorelli (35), Talavera aequipes (3), Pholcus opilionoides (4), and below 0.3 length species characteristic of the O3..6 group: Alopecosa cuneata (49), Phlegra fasciata (63) and Synageles venator(1). The ordination diagram visualizes divergent trends in succession from the initial stage $(11+2)$ to older stage $(01+2$ versus $03 . .6)$.

Species, displayed in the middle of the ordination diagram, occurred at different frequencies in all three groups and were tested for preference for a certain stage (Tab. 2). It was found that Zelotes aeneus was dominant in the initial stage but has decreased in abundance in both groups of the older stage $\left(\chi^{2}=6.56, p<0.05\right)$. Callilepis nocturna $\left(\chi^{22}=22.02, p<0.05\right)$ and Haplodrassus signifer $\left(\chi^{2}=5.99, p<0.10\right)$, on the other hand, were eudominant in the $01+2$ group. Xerolycosa miniata and Euophrys frontalis are characteristic for the 03..6 group. Xerolycosa miniata $\left(\chi^{2}=24.02, p<0.05\right)$, the most abundant species in the initial stage was also eudominant in $01+2$, and after 22 years of recovery it reached $60 \%$. E. frontalis $\left(\chi^{2}=8.45, p<0.05\right)$ showed parallel trend in the course of time.

Tab.2: Comparison of the dominance relations (\%) of the principal species in the particular stages (as a proportion in total annual captures from 6 traps)

\begin{tabular}{|lrrr|}
\hline & $\mathbf{1 1 + 2}$ & $\mathbf{0 1 + 2}$ & $\mathbf{0 3 . 6}$ \\
\hline Zelotes aeneus & 7.77 & 3.10 & 1.51 \\
Callilepis nocturna & 0.00 & 2.19 & 0.73 \\
Haplodrassus signifer & 1.28 & 7.97 & 1.45 \\
Xerolycosa nemoralis & 1.21 & 5.09 & 4.23 \\
Euophrys frontalis & 2.33 & 12.56 & 10.81 \\
Xerolycosa miniata & 19.28 & 27.67 & 58.75 \\
\hline
\end{tabular}




\section{DISCUSSION}

The composition of spiders on sites $\mathrm{O} 1$ and $\mathrm{O} 2$ was found to be more similar to that on the initial stage sites than to the composition of the rest of older stage sites. It seems that $\mathrm{O} 1+2$ group is an example of horizontal asynchronous succession, as PRACH (1987) speaks of sites of later phases where species of the initial stages re-appear. The disturbance, here, might have occurred a number of years ago, and caused these sites to develop into an anomaly uniform stage prefered by species of open habitat. Dense stands of Calamagrostis epigejos - a robust perennial plant that produce a considerable amount of hardly-degradable litter - competitively excludes other seedlings (PRACH 1988), e.g. inhibit invasion by deciduous trees. Similar inhibitory effects of Acacia extensa that resulted in uniform vegetation were recorded by MAWSON (1986) on Australian bauxite dumps. It is reasonable to expect that the sites $\mathrm{O} 1$ and $\mathrm{O} 2$ will develop into an open steppe subclimax. Whereas the O3..6 sites are supposed to develop into a ruderal steppe-forest community.

The succession on the initial stage seems to be markedly influenced by the older stage, as the 11 site (i.e. closer to the older stage sites) is resembling the community of spiders as well as the vegetation-structure of the $01+2$ group more than the 12 site which is far from the older stage.

According to the 'Intermediate Disturbance Hypothesis' (HUSTON 1979), maximum diversity is reached during the middle stages. In agreement with this hypothesis, PRACH (1987) found that maximum plant diversity was reached in about 10-15 years, which is identical to HEJKAL's (1985) findings for carabids. The latter also observed that maximum number of individuals was obtained from 6-year-old stage, while maximum species from 2-yearold stage, and both were lowest on 20 -years old stage. VOGEL \& DUNGER (1991) recorded maximum species richness of carabids and staphylinids around 3-4 years after rehabilitation. This is probably due to rehabilitation activities that hastened the succession. The diversity indexes as well as eveness in this study were found to be declining in order $11+2,01+2$ and 03..6. The results fit to the hypothesis, with the exception of the $01+2$ group that is difficult to classify.

When comparing the vegetation-structure and the composition of spiders of the dump in Novaky with dumps in other regions, it should be stressed that the area undergoing succession in Novaky is markedly smaller than dumps in e.g. north-west Bohemia, or north Moravia. Therefore, the composition of species on the dump in Novaky is more influenced by surroundings. However, there are certain similarities /or differencies recognized. 
Vegetation-structure is governed by climatic factors and each geographic region is therefore different e.g. vegetation of dumps in NW Bohemia (PRACH 1987). For example, in NW Bohemia Calamagrostis epigejos occurs after 10 years of succession together with Arrhenatherum elatius (L.). In this study Calamagrostis epigejos was recorded abundantly from the initial stage, while Arrhenatherum elatius was completely absent. However, in the age of 22 years the vegetation on dumps in both regions reach similar composition. As PRACH (1988) concludes this stage will probably last for a long time and may be considered an arrested successional stage (subclimax).

On the whole, composition of spiders is similar to those of mine dumps (of identical age) in north Moravia (MAJKUS 1988) or in Germany (BROEN \& MORITZ 1965, MADER 1985). There are a few exceptions such as Xerolycosa nemoralis and Zodarion germanicum which are replaced in this dump by the thermophilous species Xerolycosa miniata and Zodarion rubidum. This suggests that despite the difference in the area and climatic conditions, the succession of spiders on mine dumps has a comparable trend.

It should not be overlooked that the succession of spiders is more efficiently described when bearing in mind species biology. For example, cover of mosses and lichens which accumulate water offer favourable conditions for hygrophilous species such as Cicurina cicur. Sites 01 and $\mathrm{O} 2$, on the other hand, are preferred by the jumping spider Talavera thorelli that lives on dead grass stems of Calamagrostis epigejos. The ant-eating spider Zodarion rubidum lives together with the ants Myrmica sabuleti Mein. and Tetramorium caespitum L.. These ants build their nests under bare ground or with a sparse grass cover, and therefore occurred more frequently on the initial stage sites.

It is difficult to state whether any of the succession models (CONNELL \& SLATYER 1977) applied to the spider succession, since no interspecific interactions have been studied. However, from the dominance on the particular stages, it is concluded that two models - "facilitation" and "tolerance“ - can be recognized. The latter may apply to Xerolycosa miniata, whereas „facilitation“ may apply to Xysticus kochi. „Inhibition“ was only determined for vegetation-structure, in case of Calamagrostis epigejos (see above). Inevitably, more detailed study of species interactions within succession of spiders is required. 
Acknowledgment: I want to thank Prof. J.BUCHAR and Mgr. J.SVATON for the assistance given in identifying spiders and advice during study. My thanks are also due to Dr. M.STRAKOVÁ for identification of plants and Ing. J.LUTTMERDING for providing an information about the mining dump. At last but not least, I am very grateful to Dr. V.RŮŽıČKA and Dr. J.LEPŠ for comments on the manuscript, and Prof. J.D.MAJER also for some alterations to the English.

\section{REFERENCES}

BEJČEK, V. (1983): Succession and productivity of small mammals on spoil banks of the Most basin. (in Czech). - Studie ČSAV 24: 1-70

BROEN, B. von \& M.MORITZ(1965): Spinnen (Araneae) und Weberknechte (Opiliones) aus Barberfallen von einer tertiären Rohbodenkippe im Braunkohlenrevier Böhlen. - Abh. Ber. Naturkundemus. Görlitz 40/6: 1-15

CONNELL, J.H. \& R.O.SLATYER (1977): Mechanisms of succession in natural communities and their role in community stability and organization. - Am. Nat. 111: 1119-1144

DUNGER, W. (1991): Zur Primärsukzession humiphager Tiergruppen auf Bergbauflächen. - Zool. Jb. Syst. 118: 423-447

HEJKAL, J. (1985): The development of a carabid fauna (Coleoptera, Carabidae) on spoil banks under conditions of primary succession. - Acta Ent. Bohemosl. 82: 321-346

HUSTON, M.A. (1979): A general hypothesis of species diversity. - Am. Nat. 113: 81-101

HILL, M.O. (1979): DECORANA - a FORTRAN program for detrended correspondence analysis and reciprocal averaging. Ecology \& Systematics. Cornell University, Ithaca. $67 \mathrm{pp}$.

LEPŠ, J. (1988): Mathematical modelling of ecological succession - a review. - Folia Geobot. Phytotax. 23: 79-94

MADER, H.-J. (1985): Die Sukzession der Laufkäfer- und Spinnengemeinschaft auf Rohböden des Braunkohlereviers. - Schr. R. Vegetationskunde 16: 167-194

MAJER, J.D. (1990): Rehabilitation of disturbed land: long-term prospects for the recolonization of fauna. - Proc. Ecol. Soc. Aust. 16: 509-519

MAJKUS, Z. (1988): Ökologisch-faunistische Charakteristik von Arachnozönosen ausgewählter Ostrava-Bergehalden. (in Czech). - Spisy pedagogické fakulty $\vee$ Ostravě 63, Ostrava, $190 \mathrm{pp}$.

MAWSON, P.R. (1986): A comparative study of arachnid communities in rehabilitated bauxite mines. - School of Biology Bulletin 14, Perth. 45 pp.

ODUM, E.P. (1977): Fundamentals of Ecology. (In Czech). Academia, Praha. 733 pp.

PIELOU, E.C. (1966): The measurement of diversity in different types of biological collections. - J. Ecol. 48: 575-584

PRACH, K. (1987): Succession of vegetation on dumps from strip coal mining, N.W. Bohemia, Czechoslovakia. - Folia Geobot. Phytotax. 22: 339-354

PRACH, K. (1988): Life cycles of plants in relation to temporal variation of populations and communities. (In Czech). - Preslia 60: 23-40

VOGEL, J. von \& W.DUNGER (1991): Carabiden und Staphyliniden als Besiedler rekultivierter Tagebau-Halden in Ostdeutschland. - Abh. Ber. Naturkundemus. Görlitz 65/3: 1-31

Stanislav PEKÁR, Trenčianska 613/44, SK-972 71 Nováky, Slovakia 